\title{
Influence of Corporate Social Responsibility on the Performance of Organization and Commitment of the Employee: A Case of the Banking Sector of Pakistan
}

\author{
Erum Shaikh \\ University of Sindh, Jamshoro Sindh, Pakistan \\ erumshaikh0@gmail.com \\ Correspondence: erumshaikh0@gmail.com
}

Received: 25 ${ }^{\text {th }}$ August 2019; Accepted: $9^{\text {th }}$ October 2019; Published: $1^{\text {st }}$ November 2019

Abstract: Research on Corporate Social Responsibility (CSR) is not new but relatively very few researches have been focused on the influence of CSR on the organizational performance (OP), employee commitment (EC) and on the mediating role of EC with the CSR and OP. The current study was conducted on the sample size of 806 employees working in two reputable banks of Pakistan. The current study uses the PLS-SEM 3.0 version to test the proposed hypotheses. The results of current research study revealed the significantly positive link between the CSR with the performance of the organization, CSR with EC and the study also found the positive results of mediating role of EC between the CSR and OP. The study also suggests some significant future implication regarding the importance of CSR actions and its uses that can increase the commitment level of the employees, they feel proud to become part of that organizational who is socially responsible and the performance of the organization will also be enhanced.

Keywords: Corporate social responsibility; Organizational performance; Employee commitment; Social identity theory

\section{Introduction}

Corporate social responsibility (CSR) is being thought of in twenty first century that give the necessary financial tools of organizations and business hence several scholars believed that (CSR) may be necessary responsibilities of high-level managers to enhance performance of corporations (Hanzaee, K. H \& Sadeghian, M., 2014). 
The awareness of CSR has not new, discussion concerning it's began since Fifties it's since continuing for growing in significance and importance. It's subjected for bundle of commitment, debate and research (Carrol \& Shabana, 2010), so the work and research/discussion on CSR seems which can provide a lot of improvement and development in each professional person and academic communities of whole world.

CSR is concept whereby companies are committed to work for the welfare of the society and environment and improve them and these are far away from the actual obligation of the businesses. The authors further said CSR is a commitment of the organizations to improve economic conditions, improve the wellbeing of the employee's families, also enhancing the quality of life of the workers and communities which they think are good strategy to improve the growth of the businesses.

There is ample of research have been done on CSR and its relationship with the organizational performance. Review from the literature shows positive, negative and mixed results. Some studies show negative relationship of Organizational Performance with Corporate Social Responsibility (Vance, 1975), no significant relationship between Corporate Social Responsibility (CSR) and Organizational Performance (OP) (Preston, 1978; Spicer, 1980; Aupperle, K. et al. 1985; McGuire, J. et al. 1988; Davidson \& Worrell, 1990), but so many research studies identified the positive and significant relation of CSR with the OP (Moskowitz, 1972; Bragdon \& Marlin, 1979; Abott \& Monsen, 1979; Spencer \& Taylor, 1987 and Graves \& Waddock, 1994). Pava \& Krausz's (1995) detailed reviews of the empirical studies shows that the organizations have met social responsibility criteria and performed well in terms of the relationship of CSR with OP.

Orlitzky, M. et al. (2003) shows in their recent meta-analysis n study shows positive relationship between the CSR and OP. they only discuss about the financial relationship of CSr with the performance of the organization. Therefore, it is very necessary to understand and recognize the nonfinancial relationship and effect of Corporate Social Responsibility on the Organizational Performance of the banks. Banks are financial institutions which provide financial intermediary services on behalf of its customers and manage risks associated with borrowers (Greenbaum \& Thakor, 2007). Banks have a huge impact on society because they are the main player of economy. Yeung, S (2011) suggested in his research that if any bank wanted to be social responsible so the bank has to create the perspective of risk management, corporate ethics and corporate social responsibility through internal management through individuals and methods; experience advanced financial products through internal management and through external management of economic situations for the benefit of the parties concerned; and protect the rights of the customers and address the complaints of customers with setting the channels for them. Literature evidences European banks are playing active role in CSR than their counterpart banks in South Asian countries.

The understanding and practice of CSR among most of the developing nations is very limited to charitable activities, CSR has not yet fully been explored in the developed countries context including Pakistan (Galdeano, Ahmed, Fati, Rehan \& Ahmed, 2019; Jariko, Børsen, \& Jhatial, 2016). Banking Sector of Pakistan, particularly state-owned banks are relatively under-researched with respect to their role in CSR hence, more research is needed to be undertaken for deeper understanding of CSR and its importance in Organizations. Almost 95\% of the financial system of Pakistan is served by banks (Husain, 2006) therefore, it is very important to identity the performance of banking sector in the context of CSR. Secondly, effect of CSR on the performance of the organizations have been relatively unexplored in the banking sector of Pakistan and its socio- economic conditions within 
Pakistan is one of the important issues and there are so many studies have been conducted on the impact of CSR on employees' perceptions or commitment level but no any study have been conducted on the mediation role of employee organizational commitment and its influence on the performance of the organization within the context of banking sector of Pakistan in the light of social identity theory (SIT) therefore, the contribution of the study is to identify the mediating role of employee commitment with the relationship between CSR and OP (Khuwaja, Umrani, Shaikh, Ahmed \& Shar, 2019).

\section{Literature Review and Hypothesis Development}

\subsection{CSR and Organizational Performance}

According to the of Brundtland (1987), the definition of CSR is "the route of growth that meet wants and needs of current generations also their inspirations and they are not compromising the ability to meet with the needs and wants of future generation." Wood (1991), explained that the business organizations have some rules and principle of corporate social responsibility e.g. how organization can be responsive towards society, programs, policies, noticeable outcome as they're highly associated with the outcomes of social issues and relationships of organization.

Fatima, T (2019), stated the importance of CSR in the business field which is also widely discuss in current research arena, they examined the relationship between the CSR and OP in the presence of resource based prospective, the authors suggested that when any organization initiate CSR projects and become social responsible can get maximum profit from their intangibles assets, the stay further revealed that CSR has significantly positive association with OP (Jermsittiparsert, Siam, Issa, Ahmed \& Pahi, 2019). Based on general and theoretical support the CSR has positive relationship between Organizational performance, for example, the resource-based view of the organization discussed by (Branco \& Rodrigues, 2006), in their study authors recommended that the competitive advantage of the sustainability may get through applying the practices of CSR. There are enough resources within the organization but no any organization will develop the skills of the organization by only watching their competitors, that's also mentioned in the previous research and results are mixed on the relationship between the performance of organization and CSR practices, which can be stem through various reasons, few variables from them have mediating relation of CSR with the performance of the. Another past study was conducted on CSR insights that targeted typically on customers insights of CSR activities, that's paying very little attentions for workers insights, cooperation played vital role in the execution of CSR activities (Pearce \& Ensley, 2004). Many studies shared their mission which are often increased the performance of organizations and innovation effectiveness (Howell \& Frost, 1989; Pearce \& Ensley, 2004). CSR has substantial impacts upon organizational performance (Choi \& Yu, 2014). Based on the above literature review researcher have proposed the relationship of CSR with OP in the public and private banks of Pakistan:

H1: CSR will be positively related to the organizational performance.

\subsection{CSR and Employees`Organizational Commitment}

According to Meyer and Allen (2001), Employee Commitment is defined as it is psychological bond of the workers towards their organization, strength will depend on degree of employee's involvement, loyalty and belief of employees add values to organizations. Employee organizational 
commitment is considered to activate the mind of human and generate human energy to work for the betterment of their organization and become loyal employees (Jaw and Liu, 2004).

Faried, T. et al. (2019) conducted research on the employee's perception of the CSR on organizational citizenship behaviour (OCB) and employee work engagement (EWE) based on social exchange theory, the results shows positive link between the CSR with OCB and EWE. Committed employees are always considered as a greatest asset for any kind of company and companies will have to play major roles for overall profitability and efficiency for their businesses. (Hurter, 2008) argues that high level of commitment will tent to give benefits to the organisations e.g. continuous enhancement in inflows, active participation of employees in every task will be increased their efficiency, in this way the cost of the organization will be reduced. They further conclude their study with positive relation of CSR with EC.

Committed employees believed in enhancing the organisation efficiency and they feel secure at their jobs, they're well trained, feel proud in team work thus they're enjoying doing their jobs (Hsein Ho, 2009). Worker commitment has essential implications towards hiring and recruitment. Through examining key drivers of staff commitment, organizations will move list of qualities for guiding them once they are developing and recruiting committed work forces each year of organisations that will give financial support to substantial quantity of cash in developing and coaching/ training their work forces just for seeing potential, hard worker and productive staff will be applying to every jobs, and they are capable for joined competition (Ahmed \& Ogalo, 2019; Scott, 2007), they identified the positive relation of EC with CSR.

Commitment of employees resulted in best conclusion and benefits that enclosed in improved job performance, improved total return to shareholders, decrease employee's turnover, increase sales, decrease the intentions for leaving the jobs, decrease the intentions for search of alternatives, decrease absence (Brown, S., et al. 2011), the results shows that the CSR have positive association with the employee commitment. The following hypothesis is proposed by researcher based on the literature:

H2: CSR will be positively related with organizational commitment.

\subsection{Mediation of Employees`Organizational Commitment}

Researchers conducted extensive research on the relationship of CSR with EC within the organizational business context, employees' perception about the CSR and also on the effect of CSR on different stakeholders, but current research paper proposed the model in which employee organizational commitment acts as a mediator between CSR and OP. Researcher believed that this is the unique research in which researcher have combine these variables together. According to the (Stawiski et al. 2010; Imran, Ali. (2010), when organization done good actions than the employees will discuss about the activities of the organizations with outsiders and feel proud of the belongingness with the organizations and the results shows the significant and positive relationship of CSR with OC. The researcher further suggests that when any organization want to get maximum benefits from their CSR than they should involve their employees in the discussion making process about which actions of CSR should take for the welfare of the employees, communities and environment. When the employees are more influenced with the action of the CSR then the commitment level of the employees will be increased which ultimately increase the performance of the organization. Popular literature suggested the positive results with the mediating role of EC between the CSR and OP for instance, the study of Ali, I. (2010); Kim, B. J. et al. (2019) they also suggest that there is very limited 
study have been conducted on the CSR and its effects may be because of limited understanding of the importance of the CSR, therefore, based on the above discussion the following hypothesis is proposed.

H3: Employee commitment mediates the relation between CSR and performance of the organization.

\section{Methodology}

\subsection{Participants}

C.R. Kothari, (2004), stated that the concept and structure of the research design through which any research can be carry out, it will be established with the collection of data, measurement and analysis of data in a very fine way which will combine in such a way that combines the significance level with the research and economic processes.

The population of this study were the NBP and HBL, these banks have contributed hugely to organizational performance. These banks have been making large contributions to social and economic development of Pakistan economy. It was not possible for the researcher to target entire population of all branches of NBP and HBL in Pakistan to operationalize, by considering the researchers' time and dimensions, so sometimes the accommodation sample is known as available or random sample (Babbie, 1988) is used to collect the data. Sample group of this study is depending on the substances which are accessible- or close and easily accessible (Bruce L. Berg, 2001). The simple random sampling was used to collect the data.

Table 1. Respondents`Profile

\begin{tabular}{|c|c|c|c|c|}
\hline Variable & Category & $\mathrm{N}$ & Frequency & $\%$ \\
\hline \multirow[t]{2}{*}{ Gender } & Male & \multirow[t]{2}{*}{806} & 660 & 81.9 \\
\hline & Female & & 146 & 18.1 \\
\hline \multirow[t]{5}{*}{ Jon experience } & $1-5$ years & \multirow[t]{5}{*}{806} & 335 & 41.6 \\
\hline & $6-10$ years & & 299 & 37.1 \\
\hline & 11-15 years & & 88 & 10.9 \\
\hline & $16-20$ years & & 46 & 5.7 \\
\hline & 21 and above & & 38 & 4.7 \\
\hline \multirow[t]{3}{*}{ Designation } & Top management & \multirow[t]{3}{*}{806} & 196 & 24.3 \\
\hline & Middle management & & 407 & 50.5 \\
\hline & Management & & 203 & 25.2 \\
\hline \multirow[t]{4}{*}{ Age } & $18-30$ year & \multirow[t]{4}{*}{806} & 223 & 27.7 \\
\hline & $31-40$ years & & 324 & 40.2 \\
\hline & $41-50$ years & & 133 & 16.5 \\
\hline & 51 and above & & 126 & 15.6 \\
\hline
\end{tabular}

To collect the data the with the help of questionnaire is very famous especially in such cases where the population is large, so in this research study the questionnaires were sent to the concerned respondents. According to C.R. Kothari, (2004) a survey questionnaire comprises of various number of questions which are typed or printed in a different order which should be set on form or forms. The survey questionnaire was designed to gather information about linkage of CSR activities and organizational performance NBP and HBL which are located in Pakistan. The total 806 valid number 
of questionnaires were sent to the bank professionals to collect the data. The demographic profile of the participants is presented in table 1.

\subsection{Measures}

Corporate Social Performance: CSR is an independent variable measured using a 26-item adopted from the study of the Maignan \& Ferrell, (2004) the scale has six sub practices of CSR: (1) Community responsibility, (2) Environmental responsibility, (3) Employee responsibility, (4) Investor responsibility, (5) Customer responsibility and (6) Supplier responsibility with 5- point Likert scale, from ( $1=$ strongly disagree to $5=$ strongly agree).

Organizational performance: Organizational Performance is dependent variable measured by Five items adopted from the research of Gregory \& Derozdenko, (2010) with a 5-poimt Likert scale ranging from $1=$ strongly disagree to $5=$ strongly agree.

Employee Organizational Commitment: Employee Organizational Commitment is dependent variable which is measured by three items adopted from the research work of Jaworski \& Kohli, (1993) with 5-point Likert scale ranges $1=$ strongly disagree to $5=$ strongly agree.

\section{Findings}

\subsection{Partial Least Square Path Modelling}

The PLS-SEM is the variance-based technique which is very useful for the calculation of the structural path models. So, in this paper researcher has been used the structural equation modelling (SEM) through partial least square (PLS) for testing the hypotheses. PLS- SEM is very famous statistical tool from many years and it is highly accepted because of its capacity in allowing the development of the parsimonious which are predictive based model. (Hair, Ringle, and Sarstedt, 2011; Hair, Hutt, Ringle and Sarstedt, 2016). It has many advantages because PLS-SEM can ease the assumptions on any size of sample (small or large), and likewise it can forward the vigorous outcomes in the exploratory research (Chin, 2010). Since the estimations of PLS-SEM model consistently depends with respect to composites, in any case of the specification of the measurement model, the technique can process brilliantly and developmentally indicated the measurement models without the issues of identification (Hair et al. 2011). Therefore, based on these references' researcher have been used the PLS-SEM approach. The Smart PLS 3.0 by using two-stage approach was used to test the data which was proposed by Anderson \& Gerbing (1988).

\subsection{Results of Measurement Model}

The measurement model is used for all the latent variables to test the reliability, convergent validity, and discriminant validity prior to test the proposed hypotheses. The results found from the analysis of measurement model which are presented in table 2. Based on table: 2 the given values suggest that the loadings of all the latent variables are greater than 0.5 as recommended by (Barclay, Higgins, and Thompson, 1995; Chin et al. 2010). AVE is mostly used to measure convergent validity and the values of (AVE) are also greater than 0.5 in table: 2 . If the value of (AVE) equal or greater than 0.5 indicates that the variance is $50 \%$ more than its indicators. The composite reliability of the constructs (CR) are greater than 0.7 which is within the satisfactory range also suggested by (Nunnally \& Bernstein,1994; Hair, Hutt, Ringle, \& Sarstedt, 2013). The values of Cronbach Alpha of 
all the variables are greater than 0.7 which is acceptable range. The results of table: 3 indicated that the discriminant validity of all the constructs meet the standardized criteria.

Table 2. Measurement Model

\begin{tabular}{|c|c|c|c|c|c|}
\hline Construct & Item & Loading & $\begin{array}{l}\text { Cronbach's } \\
\text { Alpha }\end{array}$ & $\begin{array}{l}\text { Composite } \\
\text { Reliability }\end{array}$ & $\begin{array}{l}\text { Average Variance } \\
\text { Extracted (AVE) }\end{array}$ \\
\hline \multirow[t]{4}{*}{ Community } & COMR1 & 0.790 & 0.808 & 0.874 & 0.635 \\
\hline & COMR2 & 0.827 & & & \\
\hline & COMR3 & 0.814 & & & \\
\hline & COMR4 & 0.754 & & & \\
\hline \multirow[t]{4}{*}{ Customer } & CUSR1 & 0.780 & 0.780 & 0.858 & 0.601 \\
\hline & CUSR2 & 0.782 & & & \\
\hline & CUSR3 & 0.752 & & & \\
\hline & CUSR4 & 0.788 & & & \\
\hline \multirow[t]{5}{*}{ Employee } & EMPR1 & 0.718 & 0.797 & 0.860 & 0.552 \\
\hline & EMPR2 & 0.776 & & & \\
\hline & EMPR3 & 0.738 & & & \\
\hline & EMPR4 & 0.745 & & & \\
\hline & EMPR5 & 0.735 & & & \\
\hline \multirow[t]{4}{*}{ Environment } & ENVR1 & 0.800 & 0.811 & 0.876 & 0.638 \\
\hline & ENVR2 & 0.803 & & & \\
\hline & ENVR3 & 0.815 & & & \\
\hline & ENVR4 & 0.775 & & & \\
\hline \multirow[t]{4}{*}{ Investor } & INVR1 & 0.803 & 0.804 & 0.871 & 0.629 \\
\hline & INVR2 & 0.806 & & & \\
\hline & INVR3 & 0.768 & & & \\
\hline & INVR4 & 0.795 & & & \\
\hline \multirow[t]{3}{*}{ Org-Commitment } & EMPC1 & 0.812 & 0.736 & 0.851 & 0.655 \\
\hline & EMPC2 & 0.761 & & & \\
\hline & EMPC3 & 0.852 & & & \\
\hline \multirow[t]{4}{*}{ Org-Performance } & ORGP1 & 0.669 & 0.701 & 0.816 & 0.527 \\
\hline & ORGP2 & 0.748 & & & \\
\hline & ORGP3 & 0.717 & & & \\
\hline & ORGP4 & 0.765 & & & \\
\hline \multirow[t]{5}{*}{ Supplier } & SUPR1 & 0.743 & 0.774 & 0.847 & 0.525 \\
\hline & SUPR2 & 0.702 & & & \\
\hline & SUPR3 & 0.751 & & & \\
\hline & SUPR4 & 0.701 & & & \\
\hline & SUPR5 & 0.724 & & & \\
\hline
\end{tabular}

\subsection{Predictive Power of the Model}

The researcher has used the function of PLS Algorithm in Smart PLS 3.0 to determine the predictive power of the model, for the R2 was assessed. The R2 for the organizational employee 
commitment was calculated as (0.214) and organizational performance (0.262). The acceptable threshold value for R2 is 0.1 (Fornell \& Larcher, 1981) and values of R2 for all the variables in this research are greater than acceptable criteria of R2. The f- square option is used in PLS algorithm to obtain the effect size. The examination of $\mathrm{f}$ - square is used with $\mathrm{R} 2$ in all sizes which has effect on specific latent variables which relies upon the dependent variables can be examined (Chin, 2010).

Furthermore, to determine the effect size researcher evaluated by using the blindfolding method in smart PLS to assess the predictive relevance of the dependent latent variables, researcher figured the Q2 for cross-validated repetition (Fornell and Cha, 1994). The scores gave in Table: 4 recommend that the values of Q2 are greater than zero for both dependent variables. In this way, the model proposed predictive relevance (Chin, 1998).

\subsection{Results of Structural model}

The structural model is used to indicate the causal relationship between the constructs of the model (Sang, et al. 2010), which incorporates the assessments of the path coefficients and the value of R2, which indicate the power of prediction of the model. Along with the results of R2 and the path coefficients the loading and their significance level indicate that the data is well supported with the hypothesized model (Chin, 1998; Sang et al. 2010). The procedure of bootstrapping with almost 5000 re - samples were performed for the creation of $t$ values in 275 cases for the estimation of structural model (Hair et al. 2012; Hensler et al. 2009).

Table 3. Discriminant Validity

\begin{tabular}{lcccccccc} 
Constructs & 1 & 2 & 3 & 4 & 5 & 6 & 7 & 8 \\
\hline Community & $\mathbf{0 . 7 9 7}$ & & & & & & & \\
Customer & 0.467 & $\mathbf{0 . 7 7 5}$ & & & & & & \\
Employee & 0.544 & 0.504 & $\mathbf{0 . 7 4 3}$ & & & & & \\
Environment & 0.580 & 0.537 & 0.656 & $\mathbf{0 . 7 9 8}$ & & & & \\
Investor & 0.517 & 0.510 & 0.589 & 0.578 & $\mathbf{0 . 7 9 3}$ & & & \\
Org-Commitment & 0.363 & 0.374 & 0.398 & 0.336 & 0.340 & $\mathbf{0 . 8 0 9}$ & & \\
Org-Performance & 0.338 & 0.359 & 0.416 & 0.327 & 0.397 & 0.366 & $\mathbf{0 . 7 2 6}$ & \\
Supplier & 0.478 & 0.503 & 0.502 & 0.528 & 0.487 & 0.359 & 0.442 & $\mathbf{0 . 7 2 5}$
\end{tabular}

The results of hypotheses in table: 5 shows that the relationship between the Corporate Social Responsibility and Employee Organizational Commitment is significant $(\beta=0.463$ whereas $P<0.00)$; consequently, the hypothesis 1 is significantly supported. The relationship of CSR with OP is indicated in table: $5(\beta=0.403$ whereas $P<0.00)$ is also significant hence, the hypothesis 2 is also supported in this research study.

Table 4. Blindfolding Results

\begin{tabular}{lrrrr} 
Construct & R-squared & SSO & SSE & Q $^{2}$ (=1-SSE/SSO) \\
\hline Org-Commitment & 0.214 & $2,418.000$ & $2,097.270$ & 0.133 \\
Org-Performance & 0.262 & $3,224.000$ & $2,812.141$ & 0.128
\end{tabular}

\subsection{Mediation Results}

Various literature suggests so many methods to determine the mediators. According to Baron and Kenny (1986) said that "a mediator is a variable that accounts for all or part of the relationship 
between a predictor and an outcome". In this current research study, the bootstrapping method is used to test the mediation.

Table 5. Path Coefficients

\begin{tabular}{llllll} 
Hypotheses & Relationships & Beta & SE & t-value & Decision \\
\hline H1 & CSR -> Employ-Org Commitment & 0.463 & 0.033 & 13.832 & Supported \\
H2 & CSR -> Org-Performance & 0.403 & 0.036 & 11.226 & Supported \\
H3 & CSR -> Employ-Org ->Commitment & 0.083 & 0.020 & 4.148 & Supported \\
& Org-Performance & & & &
\end{tabular}

According to Hair et al. (2016) in mediating model, the result of indirect effect is given as significantly positive then there is the existence of mediator effect. The authors also suggest that also consider the range of confidence intervals, the range between the intervals should be small and bias should be less (Hair at al. 2016). In this research study the indirect relation between Corporate Social Responsibility and Organizational Performance is significantly positive $(\beta=0.083, p<0.00, C I L=0.051$, $\mathrm{CIU}=0.117)$ it is visibly clear the range between them is small. So, the relationship between the Corporate Social Responsibility and Organizational Performance is mediated with Employee Organizational Commitment in this study. hence, hypothesis 3 is also supported. The results of this study are inspiring and supports the prior studies for example Turkur, (2009) stated that the Corporate Social Responsibility is positive and strong predictor of Employee organizational Commitment and association between CSR and EOC is also identifies by many researchers i.e. Meyer et al. 2002; Bentley, 2006; Brammer et al. 2007. The organization who work for the wellbeing of their employees than the employees will be more committed towards their organization and work for the betterment of their organization. Hence, the performance of the organization will be increased.

\subsection{Discussion}

In this research study researcher has identified the direct relationship of corporate social responsibility with organizational performance and employee organizational commitment and also identified the mediating role of employee organizational commitment between corporate social responsibility and organizational performance. The results of current study (direct relations and mediating relations) found positive and significant as stated by many authors in their research work. (Howell \& Frost, 1989; Pearce \& Ensley, 2004) suggest that the CSR has positive relation with organizational performance. (Scott, 2007; Ho, 2009; Brown, et al. 2011), stated in their research that loyal and committed employee can enhance the performance of the organization as well as the improve the rate of return, increase sales and reduce turnover. According to (Stawiski et al. 2010; Ali et al. 2010), mediating role of employee organizational commitment will also improve the performance of the organizations.

This study contributes the facts by analyzing the $R 2$ values, predictive relevance and effect size of the proposed model by using SmartPLS $3.0 \mathrm{v}$. the values of $R 2$ of all variables (employee organizational commitment and organizational performance) of current study revealed that corporate social responsibility has positive and significant relationship with these variables.

The current study fills the gap by assessing the effect of predictive relevance and effect size of these latent variables on dependent variables i.e. employee's organizational commitment and organizational performance is small which has not been done in the previous research studies. 


\subsection{Implications for Theory and Practice}

The current research study aims to put light on the importance of theoretical, practical, Social and methodological implications. First of all, this study has provided the empirical evidence by adding the social identity theory (SIT) to test the proposed hypothesized relationship (Turkur, 2009) which stated that based on the literature of SIT it is very important for anyone's identification to become a member of organization and it will effects on their self-determination, in this way the employees will respond towards the success and failure of the organizational as their own/personal success or failure and will compare it with the success and failure of others.

As per the theory, if employees feel proud of being a member of those organizations who are socially responsible, in this way the performance and their attitude will be influenced positively (Ahmed, Mozammel \& Ahmed, 2018; Ashforth \& Mael, 1989; Dutton et al., 1994; Maignan \& Ferrell, 2001; Peterson, 2004; Brammer at al., 2005). So, it can be claimed that when the social identity of the employees will be enhanced, as a result of that as a member/employee of prestigious organization will influence on their attitudes, behavior and performance. So, this research is extending the theory by doing analysis on employee organizational commitment and organizational performance also investigate the mediation effect of employee organizational commitment between the CSR and OP which will add further knowledge.

The results of present study conclude that the corporate social responsibility has a significant and positive relation with the employee organizational commitment and organizational performance of the banks and there is also significantly positive effect of mediator i.e. employee organizational commitment between CSR and OP. the results revealed that when the organizations/ banks become social responsible and they work for the wellbeing of the society as well as for their employees than the employees will feel proud to become a member of that organization and their work performance will be increased and overall performance of the organization will also increase.

\subsection{Limitations and Future Research}

With the help of direct and indirect relation between the CSR, employee organizational commitment and Organizational performance was studies in this study among the employees of National bank of Pakistan and Habib bank limited banks of Pakistan. Based on the SIT and literature suggest that CSR practices can improve the performance of the organizations. In this study the proposed hypothesized relations are well supported with the results. therefore, the study recommends the organizations should practice CSR to get the greater performance and sustainability of their businesses. Though, this study provides much information and importance of the factors which influence on the commitment of the employees and organizational performance but still there are some limitations.

This study was conducted on the employees of the two banks of Pakistan, with 806 sample so it is suggested to the future researchers that they can investigate the role and importance of CSR towards the performance of organizations in larger scale/sample size and in different sectors/businesses or different geographic areas. This study can enhance the importance of the CSR and help the decision makers to make such policies for their employees to make them committed and loyal for the betterment of their organization, the study further encourages future researcher to add more factors which can help to extend this research and increase the commitment of the employees and increase the performance of the organizations. 


\section{Conclusion}

The results of the current study show that the CSR has a positive and significant relationship with the organizational performance. Despite of limitations the results shows that the banks who perform CSR activities have greater impact on the performance of their organizations; CSR has significantly positive relation with the employees' commitment in both banks. It is generally understandable that the organizations who have fair and transparent HR practices and initiates practices of CSR in the organizations will always regarded highly by their employees/workers (Aguilera, et al., 2007) and employee organizational commitment mediates the positive and significant relation with corporate social responsibility and organizational performance. Hence the organization who invest in CSR and start the initiatives of CSR practices can have strong bonding with their employees and employee's commitment will also be increased and will work for the betterment of their organization and the performance of the organization will be increased.

\section{References}

Ahmed, U., Mozammel, S., \& Ahmed, H. (2018). Performance on the road: examining the critical role of training effectiveness amongst the blue-collar employees in Bahrain. Asian Journal of Empirical Research, 8(9), 342-351.

Ahmed, A., \& Ogalo, H. S. (2019). From HRM to E-HRM: Contemporary Developments from Scholarly Work. Annals of Contemporary Developments in Management \& HR (ACDMHR), 1(1).

Abbott, W. F., \& Monsen, R. J. (1979). On the measurement of corporate social responsibility: Self-reported disclosures as a method of measuring corporate social involvement. Academy of Management Journal, 22(3), 501-515.

Aguilera, R. V., Rupp, D. E., Williams, C. A., \& Ganapathi, J. (2007). Putting the S back in corporate social responsibility: A multilevel theory of social change in organizations. Academy of Management Review, 32(3), 836-863.

Ali, I., Rehman, K. U., Ali, S. I., Yousaf, J., \& Zia, M. (2010). Corporate social responsibility influences, employee commitment and organizational performance. African Journal of Business Management, 4(13), 2796-2801.

Anderson, J. C., \& Gerbing, D. W. (1988). Structural equation modeling in practice: A review and recommended two-step approach. Psychological bulletin, 103(3), 411.

Ashforth, B. E., \& Mael, F. (1989). Social identity theory and the organization. Academy of Management Review, 14(1), 20-39.

Aupperle, K. E., Carroll, A. B., \& Hatfield, J. D. (1985). An empirical examination of the relationship between corporate social responsibility and profitability. Academy of Management Journal, 28(2), 446-463.

Babbie, E. R. (1988). The practice of social research. $8^{\text {th }}$ ed. Belmont: Wadsworth Publishing Company, 1998. xxiv, 465. ISBN 0-534-50468-X.

Barclay, D., Higgins, C., \& Thompson, R. (1995). The partial least squares (PLS) approach to causal modeling: Personal computer adoption and use as an illustration. Technology Studies, 2(2), 285-309.

Baron, R. M., \& Kenny, D. A. (1986). The moderator-mediator variable distinction in social psychological research: Conceptual, strategic, and statistical considerations. Journal of Personality and Social Psychology, 51(6), 1173. https ://doi.org/10.1037/0022-3514.51.6.1173

Bentley EG (2006). CSR and staff retention in New Zealand Companies: a literature review. Working Paper Series, Department of Management and International Business, Messy University, New Zealand.

Bragdon, J. H., \& Marlin, J. (1979). Is pollution profitable. Risk Management, 19(4), 9-18. 
Brammer, S., A. Millington and B. Rayton: 2005, 'The Contribution of Corporate Social Responsibility to Organisational Commitment', Working Paper, University of Bath, UK.

Brammer, S., Millington, A., \& Rayton, B. (2007). The contribution of corporate social responsibility to organizational commitment. The International Journal of Human Resource Management, 18(10), 1701-1719.

Branco, M. C., \& Rodrigues, L. L. (2006). Corporate social responsibility and resource-based perspectives. Journal of business Ethics, 69(2), 111-132.

Branco, M. C., \& Rodrigues, L. L. (2006). Corporate social responsibility and resource-based perspectives. Journal of business Ethics, 69(2), 111-132.

Brown, S., McHardy, J., McNabb, R., \& Taylor, K. (2011). Workplace performance, worker commitment, and loyalty. Journal of Economics \& Management Strategy, 20(3), 925-955.

Brown, S., McHardy, J., McNabb, R., \& Taylor, K. (2011). Workplace performance, worker commitment, and loyalty. Journal of Economics \& Management Strategy, 20(3), 925-955.

Bruce L. Berg (2001) (Qualitative Research Methods for The Social Sciences), Fourth Edition.

Brundtland, G. H. (1987). Presentation of the Report of the World Commission on Environment and Development to UNEP's 14th Governing Council Session... June 8, 1987, Nairobi, Kenya. World Commission on Environment and Development.

Carroll, A. B., \& Shabana, K. M. (2010). The business case for corporate social responsibility: A review of concepts, research and practice. International journal of management reviews, 12(1), 85-105.

Chin, W. W. (1998). The partial least squares approach to structural equation modeling. Modern Methods for Business Research, 295(2), 295-336.

Chin, W. W. (2010). How to write up and report PLS analyses. In V. V. Esposito, W. W. Chin, J. Henseler, \& H. Wang (Eds.), Handbook of partial least squares (pp. 655-690). Heidelberg, Berlin: Springer.

Choi, Y., \& Yu, Y. (2014). The influence of perceived corporate sustainability practices on employees and organizational performance. Sustainability, 6(1), 348-364.

Chu, L.-C., \& Lai, C.-C. (2011). A research on the influence of leadership style and job

Davidson, W. N., \& Worrell, D. L. (1990). A comparison and test of the use of accounting and stock market data in relating corporate social responsibility and financial performance. Akron Business and Economic Review, 21(3), 7.

Dutton, J. E., J. M. Dukerich and J. M. Harquail: 1994, 'Organizational Images and Member Identification',

Fornell, C., \& Cha, J. (1994). Partial least squares. Advanced Methods of Marketing Research, 407, 52-78.

Fornell, C., \& Larcker, D. F. (1981). Evaluating structural equation models with unobservable variables and measurement error. Journal of Marketing Research, 39-50. https://doi.org/10.1177/00222 4378101800104 Contributions to perceived organizational support and employee retention. Journal of Applied Psychology, 87(3), 565.

Galdeano, D., Ahmed, U., Fati, M., Rehan, R., \& Ahmed, A. (2019). Financial performance and corporate social responsibility in the banking sector of Bahrain: Can engagement moderate?. Management Science Letters, 9(10), 1529-1542.

Graves, S. B., \& Waddock, S. A. (1994). Institutional owners and corporate social performance. Academy of Management journal, 37(4), 1034-1046.

Greenbaum, S. I., \& Thakor, A. V. (2007). Contemporary financial intermediation. Forth Worth, Texas: Academic Press.

Hair Jr, J. F., Hult, G. T. M., Ringle, C. M., \& Sarstedt, M. (2016). A primer in partial least squares structural equation modeling (PLS-SEM) (2nd edn.). New Delhi, India: Sage publications. 
Hair Jr, J. F., Hult, G. T. M., Ringle, C. M., \& Sarstedt, M. (2016). A primer in partial least squares structural equation modeling (PLS-SEM) (2nd edn.). New Delhi, India: Sage publications

Hair Jr, J. F., Ringle, C. M., \& Sarstedt, M. (2013). Partial least squares structural equation modeling: Rigorous applications, better results and higher acceptance. Long Range Planning, 46(1-2), 1-12. Available at SSRN: https ://ssrn.com/abstr act=2233795.

Hair, J. F., Ringle, C. M., \& Sarstedt, M. (2011). PLS-SEM: Indeed a silver bullet. Journal of Marketing Theory and Practice, 19(2), 139-152. https ://doi.org/10.2753/MTP10 69-66791 90202

Hair, J. F., Sarstedt, M., Ringle, C. M., \& Mena, J. A. (2012). An assessment of the use of partial least squares structural equation modeling in marketing research. Journal of the Academy of Marketing Science, 40(3), 414433. https ://doi.org/10.1007/s11747-011-0261-6

Hanzaee, K. H., \& Sadeghian, M. (2014). The impact of corporate social responsibility on customer satisfaction and corporate reputation in automotive industry: Evidence from Iran. Journal of Islamic Marketing, 5(1), 125143.

Henseler, J., Ringle, C. M., \& Sinkovics, R. R. (2009). The use of partial least squares path modeling in international marketing. Advances in International Marketing (AIM), 20, 277-320.

Howell, J. M., \& Frost, P. J. (1989). A laboratory study of charismatic leadership. Organizational behavior and human decision processes, 43(2), 243-269.

Hsein Ho, L. C. (2009). Empowerment in a technology advanced environment. Industrial Management and Data Systems, 24-42.

Husain, I. (2006), "Pakistan banking sector", Dawn, available at: http://ishrathusain.iba.edu.pk/ speeches/WordDocs/Pakistan_Banking_Sector.doc (accessed 4 May 2006)

Hurter, N. (2008). The role of self-efficacy in employee commitment (Doctoral dissertation, University of South Africa).

Jariko, M. A., Børsen, T., \& Jhatial, A. A. (2016). CORPORATE SOCIAL RESPONSIBILITY IN PAKISTAN: ITS STATUS AND WAYS FORWARD. International Journal of Business \& Public Administration, 13(1).

Jaw, B. S., \& Liu, W. (2004). Towards an integrative framework of strategic international human resource control: The case of Taiwanese subsidiaries in the People's Republic of China. The International Journal of Human Resource Management, 15(4-5), 705-729.

Jaworski, B. J., \& Kohli, A. K. (1993). Market orientation: antecedents and consequences. Journal of marketing, 57(3), 53-70.

Jermsittiparsert, K., Siam, M., Issa, M., Ahmed, U., \& Pahi, M. (2019). Do consumers expect companies to be socially responsible? The impact of corporate social responsibility on buying behavior. Uncertain Supply Chain Management, 7(4), 741-752.

Jin, K. G., \& Drozdenko, R. G. (2010). Relationships among perceived organizational core values, corporate social responsibility, ethics, and organizational performance outcomes: An empirical study of information technology professionals. Journal of Business Ethics, 92(3), 341-359.

Khuwaja, F. M., Umrani, W. A., Shaikh, S. S., Ahmed, A., \& Shar, S. (2019). University Markor: A Context-Specific Scale to Measure Market-Orientation in Universities. SAGE Open, 9(2), 2158244019853921.

Kothari, C. R. (2004). Research Methodology: Methods \& Techniques. Second Edition

Krasodomska, J. (2015). CSR disclosures in the banking industry. Empirical evidence from Poland. Social Responsibility Journal, 11(3), 406-423.

Maignan, I. and O. C. Ferrell: 2001, 'Corporate Citizenship as a Marketing Instrument', European Journal of Marketing 35(3/4), 457-484. doi:10.1108/030905601 10382110. 
Maignan, I., \& Ferrell, O. C. (2000). Measuring corporate citizenship in two countries: The case of the United States and France. Journal of Business Ethics, 23(3), 283-297.

McGuire, J. B., Sundgren, A., \& Schneeweis, T. (1988). Corporate social responsibility and firm financial performance. Academy of Management Journal, 31(4), 854-872.

Meyer, J. P., Stanley, D. J., Herscovitch, L., \& Topolnytsky, L. (2002). Affective, continuance, and normative commitment to the organization: A meta-analysis of antecedents, correlates, and consequences. Journal of Vocational Behavior, 61(1), 20-52.

Meyer, J. P., \& Herscovitch, L. (2001). Commitment in the workplace: Toward a general model. Human Resource Management Review, 11(3), 299-326.

Moskowitz, M. (1972). Choosing socially responsible stocks. Business and Society Review, 1(1), 71-75.

Nunnally, JC, Bernstein, IH. Psychometric theory (3rd Ed.) New York: McGraw-Hill. Inc. 1994.

Orlitzky, M., Schmidt, F. L., \& Rynes, S. L. (2003). Corporate social and financial performance: A metaanalysis. Organization Studies, 24(3), 403-441.

Pava, M. L., \& Krausz, J. (1995). Corporate responsibility and financial performance: The paradox of social cost.

Pearce, C. L., \& Ensley, M. D. (2004). A reciprocal and longitudinal investigation of the innovation process: The central role of shared vision in product and process innovation teams (PPITs). Journal of Organizational Behavior, 25(2), 259-278.

Pearce, C. L., \& Ensley, M. D. (2004). A reciprocal and longitudinal investigation of the innovation process: The central role of shared vision in product and process innovation teams (PPITs). Journal of Organizational Behavior, 25(2), 259-278.

Pearce, C. L., \& Ensley, M. D. (2004). A reciprocal and longitudinal investigation of the innovation process: The central role of shared vision in product and process innovation teams (PPITs). Journal of Organizational Behavior, 25(2), 259-278.

Peterson, D. K.: 2004, 'The Relationship Between Perceptions of Corporate Citizenship and Organizational Commitment', Business \& Society 43(3), 296-319. doi:10.1177/0007650304268065.

Preston, L. E. (Ed.). (1978). Research in corporate social performance and policy (Vol. 1). Jai Press.

Sang, S., Lee, J. D., \& Lee, J. (2010). E-government adoption in Cambodia: a partial least squares approach. Transforming Government: People, Process and Policy, 4(2), 138-157.

Scott, B. (2007). What impact does training have on employee commitment and employee turnover. Kingston: University of Rhode Island.

Scott, B. (2007). What impact does training have on employee commitment and employee turnover. Kingston: University of Rhode Island.

Spencer, B. A., \& Taylor, G. S. (1987). A within and between analysis of the relationship between corporate socialresponsibility and financial performance. Akron Business and Economic Review, 18(3), 7-18.

Spicer, B. H. (1980). Market Risk, Accounting Data and Companies' pollution Control Records. Journal of Business Finance \& Accounting, 5(1), 67-83.

Stawiski, S., Deal, J. J., \& Gentry, W. (2010). Employee perceptions of corporate social responsibility. Center for Creative Leadership, Greensboro, NC.

Turker, D. (2009). How corporate social responsibility influences organizational commitment. Journal of Business Ethics, 89(2), 189.

Vance, S. C. (1975). Are socially responsible corporation's good investment risks? Management Review, 64(8), 1924. 
Wood, D. J. (1991). Social issues in management: Theory and research in corporate social performance. Journal of Management, 17(2), 383-406.

Yeung, S. (2011). The role of banks in corporate social responsibility. Journal of Applied Economics and Business Research, 1(2), 103-115.

Fatima, T., \& Arshad, F. (2019). A Resource based perspective on the link between CSR and organizational performance: Considering reputational capital as mediator. Pakistan Business Review, 20(2), 493-507.

Kim, B. J., Kim, T. H., Leroy, H., \& Simons, T. (2019, July). Unpacking a Fuzzy Link between CSR and Organizational Performance. In Academy of Management Proceedings (Vol. 2019, No. 1, p. 17282). Briarcliff Manor, NY 10510: Academy of Management.

Farid, T., Iqbal, S., Ma, J., Castro-González, S., Khattak, A., \& Khan, M. K. (2019). Employees' perceptions of CSR, work engagement, and organizational citizenship behavior: The mediating effects of organizational justice. International Journal of Environmental Research and Public Health, 16(10), 1731.

(C) 2019 by the author(s). Published by Annals of Contemporary Developments in Management \& HR (ACDMHR), under the terms and conditions of the Creative Commons Attribution (CC BY) license which can be accessed at http://creativecommons.org/licenses/by/4.0. 